\title{
PDE expression and contractility of seminiferous tubules of the human testis
}

\author{
Caroline Feuerstacke*, Sabine Tasch, Johanna Volkmann, Dieter Müller, Ralf Middendorff \\ From 5th International Conference on cGMP: Generators, Effectors and Therapeutic Implications \\ Halle, Germany. 24-26 June 2011
}

\section{Background}

In the human testis, myofibroblasts are the main cellular components of the lamina propria of seminiferous tubules. These cells are crucial for the transport of immature sperm towards the epididymis. In many cases of disturbed spermatogenesis, the peritubular lamina propria is considerably thickened, with an increase of extracellular components, resembling fibrotic changes in other organs [1]. Myofibroblast dedifferentiation was described in elderly men.

The second messenger cGMP contributes to the regulation of contractile cell function in the testis [2,3]. Sildenafil, an inhibitor of cGMP-hydrolyzing PDE5, is used in an increasing number of young patients to treat pulmonary hypertension. However, there is only scarce knowledge on PDEs in the testis and on possible effects of PDE inhibition in male reproductive organs.

\section{Materials and results}

RT PCR analyses revealed expression of all 22 PDE isoforms in the human testis. Expression pattern of PDEs within the lamina propria was characterized using laser capture microdissection (LCM) followed by RT-PCR analyses. Additional RT-PCR with primer pairs for markers of smooth muscle cells ( $\alpha$ smooth muscle actin), Sertoli cells (anti-Müller hormone) and germ cells (CatSperI), could exclude contamination with adjacent tissue during microdissection.

PDE5A, PDE3B, PDE9A and PDE10A were found in the regular lamina propria. These PDEs were also detectable in the thickened (fibrotic) lamina propria, suggesting that loss of these enzymes might not contribute to disturbed spermatogenesis associated with

\footnotetext{
* Correspondence: caroline.feuerstacke@anatomie.med.uni-giessen.de Department of Anatomy and Cell Biology, Justus Liebig University Giessen, Giessen, Germany
}

thickened lamina propria. By use of the above mentioned combination of primer pairs and additional testis biopsies displaying the absence of germ cells (Sertolicell-only syndrome) PDE5 expression in germ cells could also be shown unequivocally. The dual substrate PDEs PDE2A, PDE3A and PDE11A were only detected in intratubular cells of seminiferous tubules, but were absent from the isolated lamina propria.

Newly developed collagen gel-based assays which analyzed image stacks every 0.1 till $4 \mathrm{sec}$ monitored by a confocal microscope allowed to visualize spontaneous contractions of isolated seminiferous tubules. First data with the PDE5 inhibitor Sildenafil showed a decrease of amplitude and frequency, providing strong evidence for an essential contribution of PDE5 to regulation of tubular contractility. Spontaneous contractility of seminiferous tubules from rats after long-term treatment with sildenafil, however, was conserved.

\section{Conclusion}

The specific expression profile of PDEs in the lamina propria of the human testis and effects of PDE5 inhibition on contractility in isolated seminiferous tubules point to a well orchestrated functional interplay of PDEs for sperm transport within the testis.

\section{Acknowledgements \\ This work was supported by grants from the Deutsche \\ Forschungsgemeinschaft KFO181/1.}

Published: 1 August 2011

\section{References}

1. Volkmann J, Müller D, Feuerstacke C, Kliesch S, Bergmann M, Mühlfeld C, Middendorff R: Disturbed spermatogenesis associated with thickened lamina propria of seminiferous tubules is not caused by dedifferentiation of myofibroblasts. Hum Reprod 2011, 26:1450-1461.

2. Middendorff R, Müller D, Wichers S, Holstein AF, Davidoff MS: Evidence for production and functional activity of nitric oxide (NO) in seminiferous

\section{Biomed Central}

(c) 2011 Feuerstacke et al; licensee BioMed Central Ltd. This is an open access article distributed under the terms of the Creative Commons Attribution License (http://creativecommons.org/licenses/by/2.0), which permits unrestricted use, distribution, and reproduction in any medium, provided the original work is properly cited. 
tubules and blood vessels of the human testis. $J$ Clin Endocrinol Metab 1997, 82:4154-4161.

3. Middendorff R, Müller D, Mewe M, Mukhopadhyay AK, Holstein AF,

Davidoff MS: The tunica albuginea of the human testis is characterized

by complex contraction and relaxation activities regulated by cGMP. J Clin Endocrinol Metab 2007, 87:3486-3499.

doi:10.1186/1471-2210-11-S1-P23

Cite this article as: Feuerstacke et al.: PDE expression and contractility of seminiferous tubules of the human testis. BMC Pharmacology 201111

(Suppl 1):P23.

Submit your next manuscript to BioMed Central and take full advantage of:

- Convenient online submission

- Thorough peer review

- No space constraints or color figure charges

- Immediate publication on acceptance

- Inclusion in PubMed, CAS, Scopus and Google Scholar

- Research which is freely available for redistribution

Submit your manuscript at www.biomedcentral.com/submit
() Biomed Central 